\title{
THE LIQUIDITY AND PROFITABILITY TRADEOFF OF COMMERCIAL BANKS IN NIGERIA
}

\author{
*Adegboye, O. D. \\ *Accounting Department, Faculty of Management Sciences, Nigerian Defence Academy, Kaduna State, Nigeria \\ "Corresponding Author Email: arotile.o@yahoo.com Phone: +2347015069215
}

\begin{abstract}
This study used empirical facts and assessed the trade-off of profitability versus liquidity (and vice versa) for five commercial banks in Nigeria. Multivariate research design, regression analysis, Ordinary Least Square, and correlation coefficient approaches were used to apply quantitative methodologies to data collected. Amongst the population of twenty-two banks, Zenith, First, United Bank for Africa, Guaranteed Trust and Union Banks were chosen as case studies for this study using a purposive sample approach. Secondary data was gathered from their five-year annual reports, which were published between 2015 and 2019. The correlation coefficient was employed to test the hypothesis, which revealed that there was a statistically perfect correlation (positive and negative) between LA (loans), BA (bank advances), and MDI (marketable debt instruments) against PAT (profit after tax) and ROA (return on assets). Furthermore, since banks strive to maintain their current assets, the findings revealed that efficient liquidity management is a key determinant that may boost or impair a bank's profitability. To avoid future insolvency and bankruptcy, this study recommends that these banks use contemporary and effective liquidity management strategies amid the current post-pandemic environment. In addition, while focusing on the same topic of research, interested scholars should make significant use of a broader data coverage area.
\end{abstract}

Keywords: Banks, Commercial, Liquidity, Profitability, Trade-off, Nigeria

LICENSE: This work by Open Journals Nigeria is licensed and published under the Creative Commons Attribution License 4.0 International License, which permits unrestricted use, distribution, and reproduction in any medium, provided this article is duly cited.

COPYRIGHT: The Author(s) completely retain the copyright of this published article.

OPEN ACCESS: The Author(s) approves that this article remains permanently online in the open access (OA) model.

QA: This Article is published in line with "COPE (Committee on Publication Ethics) and PIE (Publication Integrity \& Ethics)". 


\section{INTRODUCTION}

The banking institutions of a country's financial system have a significant impact on the overall effectiveness of the financial system because they provide efficient institutional mechanisms for mobilizing and directing resources away from less productive uses and toward more productive investments (Omoseyinwa, et al., 2019). Merchant banks, commercial banks, savings banks, and development banks (including central banks) are among the key financial institutions that play these important functions. Deposit Money Banks (DMBs) are the primary financial intermediary and retail banking units in any economy, facilitating the transfer of financial assets from fund lenders (Agbada \& Osuji, 2013) to other financial assets that are more widely desired by a larger portion of people who are fund seekers (sectors of textile, agriculture, manufacturing, construction, SMEs and others) (Musa \& Rebecca, 2018).

Major performance indicators (including profitability and liquidity) are used by stakeholders such as the customers/depositors, investors, shareholders, etc. (Omoseyinwa, et al., 2019) to identify and determine their business stakes in commercial banks. Consequently, to stay competitive, banks often forgo solvency and pursue profitability alternately (Uremadu, 2018). Unfortunately, when banks focus on profitability through loans, the hurdle of meeting the depositor's demands with no notice further makes solvency issues evident, hence a trade-off decision. The highest priority of a bank's management is to pay the necessary consideration to the liquidity difficulties while strategically at intervals accommodate and grow profits that can be used to repay investments to shareholders, interests on deposits, etc. (Afolakemi, 2020).

According to Afolakemi (2020), "Risk-taking is the business of banking". Varying risks faced by banks include: interest rate, liquidity, credit, and market risks. Credit risk has the most impact on the shifting profitability levels of banks due to loans transacted to fund seekers. Credit risk arises from a counterparty's inability to fulfill contractual commitments that have been pre-pledged (Solomon, 2015; Swansie, 2016). As a result of the trade-off decisions, high liquidity levels against poor profits and low liquidity levels against high profits are produced, which may or may not be an appropriate yet professional option at that moment. Depending on multiple factors such as credit score, annual income, and debt ratios of clients, personal loan interests range from 5\% to 36\%, interest rates as of July 2019 is at $28.2 \%$ (average personal loan interest monthly) and lending rates at $15.46 \%$ Annual Percentage Rate (APR) while the deposit interest rate is currently around 9.48\% (BankRate, 2020; Newton \& Nwosu, 2019). Thus, this shows the extent to which banks under stringent regulations must maintain their current assets and create wealth through the spread of interests on deposits and loans granted.

This study was unable to find existing up to date literature on the subject of discourse and thus, provides this both empirically and analytically while using marketable debt instruments, different from other literatures. Additionally, this study examined the relationship that exists between profitability and liquidity, cost of both liquidity and illiquidity as competing objectives and a critical view of various liquidity measures adopted by these banks in effecting changing levels on their profitability.

\section{RESEARCH QUESTIONS}

a. Do loans granted to customers significantly determine banks' profitability levels?

b. What is the existing relationship between banks' advances and profitability? 
c. What is the extent to which banks' liquid funds affect their overall profitability?

\section{RESEARCH OBJECTIVES}

a. Examine the extent to which the amount of loans granted by banks determine their profitability levels.

b. To establish the relationship between commercial banks' advances and profitability

c. To examine the liquid funds of commercial banks and how it affects their overall profitability.

\section{REVIEW OF LITERATURE}

There have been several research studies relatable to the subject with the most recent in 2019. Some of them include: Omoseyinwa, et al. (2019) in their study on "Liquidity and profitability dynamics" examined 10 banks between 2008 and 2017 and used estimation techniques of ordinary least square method (regression) producing a statistically significant relationship between two selected liquidity management proxies (current ratio and liquidity ratio) and profitability (return on asset). However, there was no empirical evidence in support of other liquidity variables expressed in ratios influencing the profitability of the selected banks.

Ozogbuda (2019) in his study on "non-performing loans and profitability of deposit money banks in Nigeria" heightened the unending dynamics of how loans affected sampled banks' performance. Results from the analysis revealed that bank credit policy has a statistically positive relationship with proxies on performance but a negative relationship with inflation rate. The study recommended that banks in Nigeria regulate lending based on fluctuations of inflation rates varying by periods and loans granted should be charged with interest elements that favor easy repayment as reflected in banks' credit policies.

Amahalu, Abiahu, and Chinyere (2017) in their study on "loan management and financial performance of quoted deposit money banks in Nigeria" revealed a statistically significant relationship between loan management proxy by non-performing loan and deposits and financial performance depicted with return on assets, earnings per share, dividend per share of banks quoted on the Nigerian Stock Exchange (NSE). The study recommended that the Nigerian apex bank and its regulatory bodies further restrict and effect compliance to banks, relevant provisions of Banks and Other Financial Institution Act (BOFIA) (1999), and prudential guidelines.

Asara, Neil, Jupftar and Regina (2012) in their study assessed the influence of liquid funds on return on assets (ROA) for 46 quoted firms in Nigeria across various sectors between 2001 and 2010. Regression analysis was adopted with the dependent variable- return on assets regressed against liquid funds (independent variable). It revealed a positive relationship that was statistically significant to profitability. Additionally, the study revealed that liquid funds especially cash is greatly influenced the rise in liquidity variable but excluded marketable securities like bills, government securities, and call money.

\section{MATERIALS AND METHODS}

This study adopted a multivariate yet descriptive research design. It quantitatively utilized loans (LA), bank advances (BA), and marketable debt instruments (MDI) as proxies for liquidity while profit after tax (PAT), and return on assets (ROA) were proxies for profitability. The sample size (5 out of 22 commercial banks) was selected based on the criteria that there is availability of consistent data-set for five years (2015-2019), there was no merger during the study 
period, have at least a branch across the states of the federation, and are listed and quoted on the Nigerian Stock Exchange (NSE). To ensure validity and reliability of the data collected, only published data in the form of financial statements which is a requirement by law was used.

\section{MODEL SPECIFICATION}

Modifying models of Uremadu (2018), Ozogbuda (2019), Ibe (2013), and Afolakemi (2020), this study utilized regression analysis and Ordinary Least Squares (OLS) (estimation technique) and hypothesis tested with Pearson correlation to establish the correlation between liquidity and profitability amongst the listed variables. The statistical package used to run the regression models for this research was the Microsoft Excel software 2019.

$$
\begin{aligned}
& Y_{1}=b_{0}+b_{1} X_{1}+b_{2} X_{2}+b_{3} X_{3}+e \ldots \ldots \ldots . .(\text { Equation } 1) \\
& Y_{2}=b_{0}+b_{1} X_{1}+b_{2} X_{2}+b_{3} X_{3}+e \ldots \ldots \ldots \ldots(\text { Equation 2) }
\end{aligned}
$$

Where: $\mathrm{Y}=$ Profitability representing the dependent variable;

$\mathrm{b}_{0}, \mathrm{~b}_{1}, \mathrm{~b}_{2}, \mathrm{~b}_{3}$; are regression parameters or coefficients;

$\mathrm{X}_{1} \mathrm{X}_{2} \mathrm{X}_{3}$; are independent variables;

$\mathrm{X}_{1}=$ Bank Advances (BA).

$\mathrm{X}_{2}=$ Marketable Debt Instruments (MDI).

$\mathrm{X}_{3}=$ Loans $(\mathrm{LA})$

Therefore, $\mathrm{PAT}=\mathrm{b}_{0}+\mathrm{b}_{1} \mathrm{BA}++\mathrm{b}_{2} \mathrm{MDI}+\mathrm{b}_{3} \mathrm{LA}+\mathrm{e}$;

$\mathrm{ROA}==\mathrm{b}_{0}+\mathrm{b}_{1} \mathrm{BA}+\mathrm{b}_{2} \mathrm{MDI}+\mathrm{b}_{3} \mathrm{LA}+\mathrm{e}$

\section{RESULTS}

From table 1.2, the standardized results show that based on loans given out by these banks, it has a significant positive impact on performance with an estimated standardized coefficient of 0.324 (Sig. $=0.000$ ). Unfortunately, all other banks failed to produce a significant relationship between loans and PAT. Ordinarily, banks source profits from loans and advances but attached are several risks particularly credit risk. Examining at 95\% accuracy of data, i.e., at 5\% significance level, it can be deduced that for every 1million declared as profit, there is a positive influence of 0.024 , 0.032, and 0.041 for FBN, UNB, and ZBN while a decrease in PAT for every million declared for GTB and UBA. The only significant value for $\mathrm{p}$-value is 0.01 for UNB where $\mathrm{p}<0.05$. Additionally, when variables sum of LA for each bank is analyzed against PAT, $\alpha=8 \%$ which is assumed insignificant.

The loan and advances figures include some bad debts and irrecoverable loan contracts in this study. From table 1.3, all adjusted R-square except that of FBN, GTB, and UNB are significant of the variations in PAT and can be accounted for by the independent variable-BA. The standardized results show that based on advances given out by these banks, it has a significant positive impact on performance with an estimated standardized coefficient at Sig. $=$ 0.000. A significant R-square was produced when all sum of BA matched against PAT for 5years. At $5 \%$ significance level, coefficients of advances for FBN, UNB, and ZBN are positive while there is a decrease for GTB and UBA. Therefore, based on regression results, when variables sum of BA for each bank is analyzed against PAT, $\alpha=0.015$ 
approximately $1.5 \%$ which is assumed significant. For individual banks, $\alpha 0.04$ i.e., $4 \%$ for FBN are considered significant.

For this study, marketable debt instruments (MDI) include debt securities redeemable within a year. Considering the high liquidity advantage of MDI to banks, treasury bills, option securities, and short-term derivatives were considered. From table 1.4, it can be interpreted that based on MDI invested by these banks to mitigate illiquidity, it has a significant positive impact on PAT (profitability) with an estimated standardized coefficient of 0.438 and 0.055 (Sig. = 0.000). At 5\% significance level, the MDI coefficients have a positive influence for all five banks. Also, when variables sum of MDI for each bank is analyzed together against PAT, $\alpha=0.18$ approximately $18 \%$ which is insignificant. For individual banks, $\alpha$ is 0.001 i.e., $0.1 \%$ for $\mathrm{ZBN}$ is considered significant while other individual banks have insignificant p-values.

\section{TEST OF HYPOTHESIS}

Pearson correlation reveals the linear relationship between variables with a set or two sets of data. The Pearson correlation can be written in forms: "the Greek letter rho $(\rho)$ for a population and the letter "r" for a sample" (KSU, 2021). The value of $r$ is always between $+1,0$, and -1 . Zero correlation shows no relationship and +1 or -1 shows a perfect relationship (positive/negative) between variables in the dataset. Consequently, $a+1$ reveals that an increase in a variable result in an increase in the other, -1 means that for every positive increase in one variable, there is a negative decrease of 1 in the other, and zero reveals that for every increase, there is neither a positive nor negative increase (Ibid).

$H_{01:}$ There is no significant relationship between loans and banks' profitability in Nigeria

As shown in table 1.5, therefore, this can be interpreted that there is a perfect (positive) correlation between LA and PAT; LA and ROA. The banks' liquidity is associated with a +1 increase in both PAT and ROA. Values 0.987092 and 0.988525 can be approximated to 1 , therefore, $\mathrm{H}_{01}$ should not be accepted and an alternative hypothesis accepted stating that LA has a significant relationship with PAT and ROA with the above values at +1 .

\section{$\boldsymbol{H}_{02:}$ There is no significant relationship between advances and profitability}

Also, table 1.5 depicts a correlation of (-0.98133) between banks' liquidity (represented by BA) and profitability (represented by PAT). Approximately, -0.98133 can be represented as -1 . Therefore, for every increase in BA granted, a perfect decrease of -1 in PAT is evident. On the results of ROA against BA, the result produces 0.98335 . This shows a perfect increase of +1 in PAT if approximated. Therefore, for this study, the alternative hypothesis that states 'there is a significant relationship between liquidity and profitability' is accepted.

$\boldsymbol{H}_{03:}$ There is no significant relationship between liquid funds and the profitability of banks in Nigeria

Similarly, there exist a significant relationship between MDI and PAT; MDI and ROA. Based on the available data, it can be assumed that for every increase in investments represented as MDI variable, there is a positive increase of

0.86601 (cannot be approximated to 1) in PAT and +1 ROA. Thus, this research does not accept the null hypothesis 
but accepts the alternative hypothesis which states that there is a significant relationship between liquid funds and profitability of banks in Nigeria. This means that (short-term) liquid funds convertible to cash within a year can positively influence a financial manager's decision to invest more or less and contribute to profit in the long run while representing a liquidity shock in the period of financial distress.

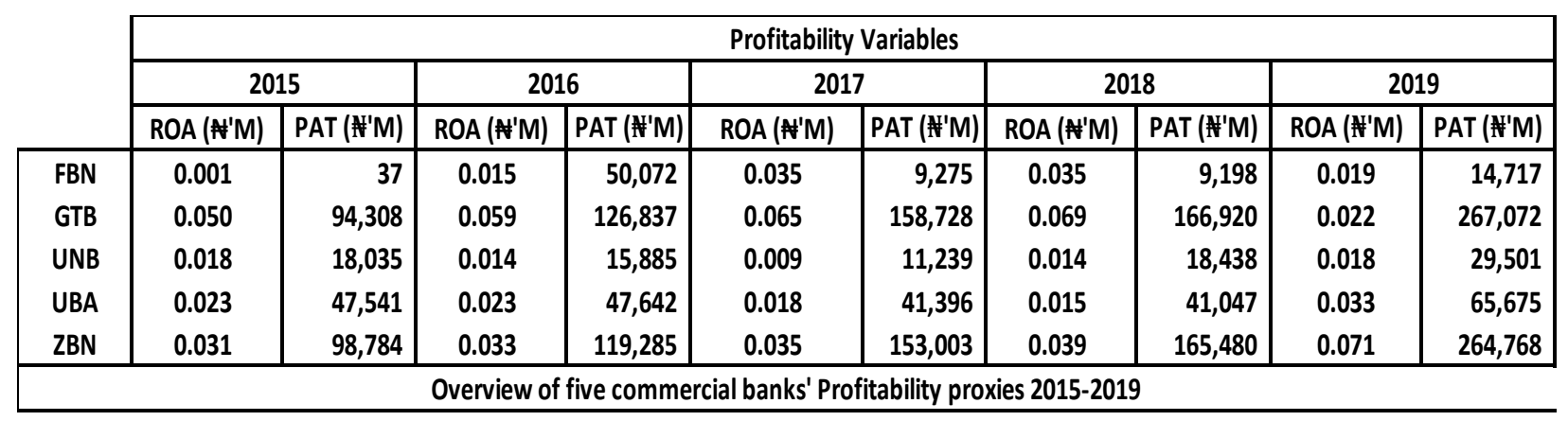

\begin{tabular}{|c|c|c|c|c|c|c|c|c|c|c|c|c|c|c|c|}
\hline & \multicolumn{15}{|c|}{ Liquidity Variables } \\
\hline & \multicolumn{3}{|c|}{2015} & \multicolumn{3}{|c|}{2016} & \multicolumn{3}{|c|}{2017} & \multicolumn{3}{|c|}{2018} & \multicolumn{3}{|c|}{2019} \\
\hline & $B A\left(A^{\prime} M\right)$ & $\mathrm{LA}\left(\mathrm{F}^{\prime} \mathrm{M}\right)$ & MDI (\#'M) & $\mathrm{BA}\left(\mathrm{A}^{\prime} \mathrm{M}\right)$ & 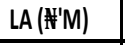 & MDI (\#'M) & $B A\left(A^{\prime} M\right)$ & $\mathrm{LA}\left(\mathrm{A}^{\prime} \mathrm{M}\right)$ & MDI (\#'M) & $\mathrm{BA}\left(\mathrm{A}^{\prime} \mathrm{M}\right)$ & $\mathrm{LA}\left(\mathrm{\#}^{\prime} \mathrm{M}\right)$ & MDI (\#'M) & $\mathrm{BA}\left(\mathrm{A}^{\prime} \mathrm{M}\right)$ & $\mathrm{LA}\left(\mathrm{F}^{\prime} \mathrm{M}\right)$ & MDI (\#'M) \\
\hline FBN & 293,316 & $1,163,969$ & 1,865 & 239,775 & $1,452,937$ & 8,317 & 5,949 & 108 & & 16,557 & 110 & 3,427 & 29,803 & 120 & 3,513 \\
\hline GTB & 134,715 & $1,074,771$ & 12,375 & 167,491 & $1,281,174$ & - & $1,399,934$ & 970,340 & 12,528 & 140,654 & 970,343 & 56,291 & 253,177 & $1,057,674$ & 57,698 \\
\hline UNB & 11,565 & 370,949 & 52,843 & 14,887 & 518,349 & 26,407 & 33,478 & 531,807 & 4,060 & 45,359 & 473,396 & 24,523 & 81,646 & 516,002 & 25,136 \\
\hline UBA & 227,669 & 822,694 & 189,644 & 276,308 & $1,090,355$ & 52,295 & 183,961 & $1,204,426$ & 7,259 & 13,321 & $1,274,112$ & 5,332 & 23,978 & $1,388,782$ & 5,465 \\
\hline ZBN & 473,203 & $1,884,941$ & 330,900 & 551,798 & $1,289,864$ & 463,787 & 480,392 & $1,253,817$ & 799,992 & 178,740 & $1,353,101$ & 817,043 & 321,732 & $1,474,880$ & 837,469 \\
\hline \multicolumn{16}{|c|}{ Overview of five commercial banks' Liquidity proxies 2015-2019 } \\
\hline
\end{tabular}

Table 1.1- Overview of Banks' liquidity and profitability proxies 2015-2019; Source: Annual Reports of five banks (all values are expressed in millions of the Nigerian Naira)

Where: PAT = Level of profitability; ROA= return on assets; $\mathbf{B A}=$ Bank advances;

LA = bank loans; MDI= Marketable debt instruments. FBN, GTB, UNB, UBA, and ZBN represent First Bank,

Guarantee Trust Bank, Union Bank, United Bank for Africa, and Zenith Bank Plc. respectively.

\begin{tabular}{|c|c|c|c|c|c|c|}
\cline { 2 - 7 } \multicolumn{1}{c|}{} & FBN & GTB & UBA & UNB & ZBN & All 5 BANKS \\
\hline R Square & 0.42886 & 0.2577859 & 0.105301203 & 0.80620983 & 0.566785 & 0.83399 \\
Adjusted R Square & 0.23848 & 0.0664536 & -0.19293173 & 0.64997429 & 0.321245 & 0.69554 \\
Observations & 5 & 5 & 5 & 5 & 5 & 5 \\
\hline Regression & 1 & 1 & 1 & 1 & 1 & 1 \\
Residual & 3 & 3 & 3 & 3 & 3 & 3 \\
Total & 4 & 4 & 4 & 4 & 4 & 4 \\
\hline SS Regression & $1.972 \mathrm{E}+09$ & 338907379 & 5854433.395 & 32209757.4 & $1.348 \mathrm{E}+09$ & $2.006 \mathrm{E}+11$ \\
F-test & 2.252648 & 0.213552 & 0.353083754 & 5.57079892 & 1.4198571 & 6.8536098 \\
\hline Co-efficient: & \multicolumn{7}{|c|}{} \\
\hline Intercept & 5482.6228 & 216290.09 & 50730.31433 & 432580.187 & 9137.7047 & 154492.92 \\
loans & 0.0243758 & -0.071867 & -0.0069325 & 0.032432 & 0.0408045 & 0.0873373 \\
Std Error & 0.016241 & 0.1555163 & 0.011666773 & 0.01433 & 0.0342441 & 0.0333611 \\
P- value & 0.2303722 & 0.6754492 & 0.594202 & 0.09938 & 0.3191016 & 0.7914166 \\
\hline
\end{tabular}

Table 1.2-Regression results for five banks based on LA and PAT variables from 2015-2019; source: Researcher. 


\begin{tabular}{|c|c|c|c|c|c|c|}
\cline { 2 - 7 } & FBN & GTB & UBA & UNB & ZBN & All 5 BANKS \\
\hline R Square & 0.88600 & 0.5873458 & 0.1053012 & 0.8062098 & 0.77366785 & 0.88801 \\
Adjusted R Square & 0.84793 & 0.6311677 & -0.0029317 & 0.9742875 & 0.321245 & -0.32282 \\
Observations & 5 & 5 & 5 & 5 & 5 & 5 \\
\hline Regression & 1 & 1 & 1 & 1 & 1 & 1 \\
Residual & 3 & 3 & 3 & 3 & 3 & 3 \\
Total & 4 & 4 & 4 & 4 & 4 & 4 \\
\hline SS Regression & $1.172 \mathrm{E}+09$ & 388879379 & 4466433.78 & 76207447 & 1877298660 & 95864223.28 \\
F-test & 2.3343153 & 0.3235135 & 0.30383889 & 3.8005927 & 1.98785111 & 0.023844628 \\
\hline Co-efficient: & \multicolumn{7}{|c}{} & \\
\hline Intercept & 33282.798 & 290661.040 & 73050.470 & 581322.081 & 55471.329 & 352660.854 \\
BA & 0.0175714 & -0.0166765 & -0.0009875 & 0.0256432 & 0.0400577 & -0.0080614 \\
Std Error & 0.0240458 & 0.1375263 & 0.0711915 & 0.0143300 & 0.0234156 & 0.0522057 \\
P- value & 0.0370729 & 0.4219420 & 0.4277650 & 0.0993800 & 0.1141164 & 0.0145031 \\
\hline
\end{tabular}

Table 1.3-Regression results for five banks based on BA and PAT variables from 2015-2019; source: Researcher.

\begin{tabular}{|c|c|c|c|c|c|c|}
\cline { 2 - 7 } \multicolumn{1}{c|}{} & FBN & GTB & UBA & UNB & ZBN & $\begin{array}{c}\text { All 5 } \\
\text { BANKS }\end{array}$ \\
\hline R Square & 0.88578 & 0.7785877 & 0.443333312 & 0.34552111 & 0.6223288 & 0.92210 \\
Adjusted R Square & 0.84793 & 0.0459677 & 0.079317291 & 0.94287511 & -0.511151 & 0.98905 \\
Observations & 5 & 5 & 5 & 5 & 5 & 5 \\
\hline Regression & 1 & 1 & 1 & 1 & 1 & 1 \\
Residual & 3 & 3 & 3 & 3 & 3 & 3 \\
Total & 4 & 4 & 4 & 4 & 4 & 4 \\
\hline SS Regression & $1.008 \mathrm{E}+09$ & $1.01 \mathrm{E}+09$ & 336677.3948 & 10065757.6 & $2.981 \mathrm{E}+10$ & $6.1 \mathrm{E}+10$ \\
F-test & 2.252648 & 0.253452 & 0.083886676 & 5.24087066 & 1.376983 & 6.8271354 \\
\hline Co-efficient: & & & & & \\
\hline Intercept & 7198.7976 & 7334290.9 & 59930.89743 & 14668581.8 & 11997.996 & 22322277 \\
MDI & 0.4375757 & 0.0865447 & 0.000130421 & 0.05546786 & 0.0010558 & 0.0173373 \\
Std Error & 0.0098546 & 0.5564865 & 0.773118875 & 0.03314754 & 0.0244134 & 0.0222336 \\
P- value & 0.4417778 & 0.54492 & 0.42432207 & 0.3393864 & 0.0010166 & 0.1899917 \\
\hline
\end{tabular}

Table 1.4-Regression results for all five and individual banks based on MDI and PAT variables form 2015 2019; source: Researcher

\begin{tabular}{|l|r|r|r|r|r|}
\hline & \multicolumn{1}{c|}{$\boldsymbol{P A T}$} & \multicolumn{1}{c|}{$\boldsymbol{R O A}$} & $\boldsymbol{B A}$ & \multicolumn{1}{c|}{$\boldsymbol{L A}$} & \multicolumn{1}{c|}{$\boldsymbol{M D I}$} \\
\hline PAT & 1 & & & & \\
\hline ROA & 0.999467 & 1 & & & \\
\hline BA & -0.98133 & 0.985335 & 1 & & \\
\hline LA & 0.987092 & 0.988525 & 0.996087 & 1 & \\
\hline MDI & 0.866012 & 0.986799 & 0.967855 & 0.983375 & 1 \\
\hline
\end{tabular}

Table 1.5 (Researcher's computation) 
Table 1.6 Summarry of Hypothesis

\begin{tabular}{|c|c|c|c|}
\hline $\mathrm{S} / \mathrm{N}$ & Hypothesis & Null/Alternative & Results \\
\hline \multirow[t]{2}{*}{1} & $\begin{array}{l}\text { There is no significant relationship between loans and } \\
\text { commercial banks' profitability in Nigeria. }\end{array}$ & $\mathrm{H}_{0}$ & Rejected \\
\hline & $\begin{array}{l}\text { There is a significant relationship between loans and } \\
\text { commercial banks' profitability in Nigeria. }\end{array}$ & $\mathrm{H}_{1}$ & Accepted \\
\hline \multirow[t]{2}{*}{2} & $\begin{array}{l}\text { There is no significant relationship between advances and } \\
\text { profitability }\end{array}$ & $\mathrm{H}_{0}$ & Rejected \\
\hline & $\begin{array}{l}\text { There is a significant relationship between advances and } \\
\text { profitability }\end{array}$ & $\mathrm{H}_{1}$ & Accepted \\
\hline \multirow[t]{2}{*}{3} & $\begin{array}{l}\text { There is no significant relationship between liquid funds and } \\
\text { profitability of commercial banks in Nigeria. }\end{array}$ & $\mathrm{H}_{0}$ & Rejected \\
\hline & $\begin{array}{l}\text { There is a significant relationship between liquid funds and } \\
\text { profitability of commercial banks in Nigeria. }\end{array}$ & $\mathrm{H}_{1}$ & Accepted \\
\hline
\end{tabular}

\section{DISCUSSION}

From the analysis above, effective liquidity management is indeed one of the most crucial problems relative to decisions that may mar or improve operations of DMBs generally. Although, the selected variables (LA, BA, MDI) have a strong influence in terms of their contribution towards their performance (PAT/ROA), however, evidently, management of these key profit contributors in the five selected banks contributing positively is imperative. The BA and MDI variables in all five banks did not contribute as much but certainly has a high degree of influence on their performance. LA showed a high strength of influence of all five banks on profitability. In line with the current global trend where liquidity has become a constant source of anxiety to the financial sector, the results above have not shown otherwise.

Despite the presence of other factors which are more related to general economic such as inflation rates as expressed by Ozogbuda (2019), regulatory and statutory elements, the results presented above have shown to be inverse in nature depending on how efficiently or effectively the banks' financial decisions are at different time intervals. However, the reliability of the results and analysis can be used for further analysis to distinctively specify and identify other factors not covered in this study. Additionally, quantitative methods such as regression analysis and correlation coefficient similar to Afolakemi (2020), Agbada and Osuji (2013), Thomas and Oke (2013), Kinjar and Kumar (2017) and Ozogbuza (2019), has not only quantified the degree of influence the selected variables have on banks' profitability and performance but has also presented a clearer picture of each of the discussed variables.

\section{CONCLUSION}

It is no gainsaying that the survivals of DMBs depend greatly on efficient liquidity management and profitability simultaneously and otherwise. Considerably, since there is usually disagreement between profitability and liquidity coupled with Nigerian commercial banks strife to manage their current assets, this research study analytically examined the authenticity or otherwise of this notion with a central focus on commercial banks in Nigeria and to understand the disagreements (if any) and how they can be resolved. 
Therefore, these banks should not streamline their profit maximization goals but also adopt prompt measures that will ensure effective liquidity management which will minimize and avoid cases of excessive and deficient liquidity. For example, instead of keeping idle/excessive cash in vaults as a provision for unexpected withdrawal demands of their depositors, these banks could resort to borrowing and discounting bills while surplus funds could be seasonally invested in short-term instruments of the money market. To maintain sufficient liquidity at all times, this study recommends that banks attempt to schedule the maturity periods of their secondary reserve assets to correspond to the period in which the funds will be needed. It may be impossible to determine when most depositors would demand their funds, however, with the use of current applications and internet banking packages, this could go a long way for business customers who have scheduled withdrawal dates.

Furthermore, to avoid future insolvency and bankruptcy, this study recommends that Nigerian banks use contemporary and effective liquidity management strategies amid current post-pandemic environment.

\section{CONFLICT OF INTEREST}

There were no conflicts of interest.

\section{REFERENCES}

Afolakemi, O. (2020). Effective Relativity of Profitability and Liquidity with Credit Management. Empirical Evidence from Nigeria. (P. M. Ajayi, Ed.) Department of Accounting and Finance, Ajayi Crowther University Chapter, $5-18$.

Agbada, A., \& Osuji, C. (2013). The Efficacy of Liquidity Management and Banking Performance in Nigeria. International Review on Management and Business Research (2), 1, 9, 11, 12, 31.

Amahalu, N., Abiahu, M. F., \& Chinyere, O. (2017). Loan Management and Performance of Nigerian Commercial Banks. SSRN, 30-43.

Asara, S., Chernenkol, N., Ishaan, J., \& Ananya, R. (2012). Liquid Fund Management: Evidence from Listed Companies, Nigerian Stock Exchange. NBER, Working Paper Series , 11-19. doi:10.3386/w22381

BankRate. (2020, September 14th ). Retrieved from Bankrate.com: www.bankrate.com

Kinjar, D., \& Kumar, A. (2017). Priority Lending of Commercial Banks in India. Science Direct, 12-22.

KSU. (2021, July 8th). Kent State University. Retrieved from https://libguides.library.kent.edu/SPSS/PearsonCorr

Musa, K., \& Rebecca, O. (2018). The Efficay of Banking Services in a Modern Economy. Science Direct, 1-15.

Newton, I., \& Nwosu, G. (2019). Commercial Bank Risk Management Working Paper Series: An Analysis of the Process. (W. School, Ed.) 41-61.

Omoseyinwa, K., Taylor, H., Adelaja, S., Adam, T., Badmus, A., \& Titilope, O. (2019, October 15). Liquidity and profitability dynamics: evidence from the Nigerian banking sector. International Journal for African Economic Research, 3(2), 11-16. doi:11.13876 
Ozogbuda, S. (2019, July). Non-performing Loans and the Profitability of Deposit Money Banks in Nigeria. Research Gate, 2(2), 11, 19. doi:10.5281

Solomon, A. (2015). Profitability and Liquidity. Critical Financial Banking Decisions in Nigeria. Mozambique Journal for Economics and Business, 4(1), 9.

Swansie, M. (2016). The Banking System in Nigeria. The Zambezie Journal of Banking and Finance, 11-42.

Thomas, A., \& Oke, M. (2013). Liquidity and Profitability of Nigerian Banks. (A. C. Department of Accounting and Finance \& Department of Economics, Ed.) Journal of Economics and Sustainable Development, Ajayi Crowther University, Oyo, Vol.4, No.6, 2013(2222-1700). Retrieved 2013

Uremadu, S. (2018). A Review of Bank Loans to Farmers: Implications for Agricultural Diversification in Nigeria. Research Gate. doi:10.31031/MCDA.2018.02.000542 